\title{
Prevalence of haemoparasites, leptospires and coccobacilli with potential for human infection in the blood of rodents and shrews from selected localities in Tanzania, Namibia and Swaziland ${ }^{\dagger}$
}

\author{
Abdul A.S. Katakweba ${ }^{1 *}$, Loth S. Mulungu', Seth J. Eiseb², \\ Themb'alilahlwa A. Mahlaba ${ }^{3}$, Rhodes H. Makundi', \\ Apia W. Massawe', Benny Borremans ${ }^{4} \&$ Steven R. Belmain ${ }^{5}$ \\ ${ }^{1}$ Pest Management Centre, Sokoine University of Agriculture, P.O. Box 3110, Chuo Kikuu, Morogoro, Tanzania \\ ${ }^{2}$ National Museum of Namibia, P.O. Box 1203, Windhoek, Namibia \\ ${ }^{3}$ Department of Biological Sciences, University of Swaziland, Private Bag 4, Kwaluseni, Swaziland \\ ${ }^{4}$ Evolutionary Ecology Group, University of Antwerp, Belgium \\ ${ }^{5}$ Natural Resources Institute, University of Greenwich, Central Avenue, Chatham Maritime, Kent ME4 4TB, U.K. \\ Received 1 March 2011. Accepted 3 February 2012
}

\begin{abstract}
The prevalence of haemoparasites, leptospirosis and Yersinia pestis was investigated in rodents and shrews from Tanzania, Namibia and Swaziland. Blood smears originating from rodents and shrews from the three countries indicated the presence of Trypanosoma lewisi (72.7\%; $n=950)$, Bacillus spp. (25.6\%; $n=950)$, Borrelia sp. $(0.01 \% ; n=950)$ and bipolar coccobacilli $(0.01 \% ; n=950)$. The blood smears from Namibia $(n=26)$ had no haemoparasites while only $1.33 \%(n=75)$ of those from Swaziland showed presence of T. lewisi. Leptospira interrogans was found in rodent blood sera from Tanzania in the following serogroup proportions $(n=350)$ : Icterohaemorrhagiae $(10.29 \%)$, Pomona $(2.86 \%)$, Hardjo $(1.14 \%)$, Bullum $(0.86 \%)$, Grippotyphosa $(1.43 \%)$ and Canicola $(1.14 \%)$. Serodiagnosis of antibodies against the $\mathrm{F} 1$ antigen of $Y$. pestis using the enzyme linked immunosorbent assay (ELISA) was negative for all the serum samples from central Tanzania, while two samples of serum from two species of rodents, Rhabdomys pumilio and Gerbilliscus leucogaster, collected in the Kavango Region of Namibia were positive. These results suggest an enzootic plague activity in this region in Namibia. It is concluded that zoonotic agents, that are infectious to humans, are prevalent in rodents and shrews in the three countries, and that local communities should apply rodent control measures to reduce the risk of human infections.
\end{abstract}

Key words: haemoparasites, plague, leptospirosis, Africa, rodents.

\section{INTRODUCTION}

Rodents and shrews play an important role as reservoirs and hosts of many pathogens of animal and public health importance (Gratz 1994) globally. Agents of rodent-borne zoonoses include viruses, bacteria, rickettsia, protozoa and helminths (Gratz 1994, 1997). Infections with zoonotic haemoparasites are widespread in wild rodents (Korbawiak et al. 2005). They include borrelia, trypanosomes, bacilli, plasmodia and coccobacilli (Silayo 1992; Gratz 1997; Juha et al. 2003; Powelczyk et al. 2004). In humans, these pathogens are responsible for many rodent-borne diseases including plague,

\footnotetext{
Paper presented at the 4th International Conference on Rodent Biology and Management (ICRBM), 12-16 April 2010, Bloemfontein, South Africa.

*Author for correspondence. E-mail: katakweba@suanet.ac.tz/ selemani.abdul@yahoo.com
}

leptospirosis, toxoplasmosis, leishmaniasis and haemorrhagic fevers. Leptospirosis and plague are believed to be widespread in East and southern Africa (Machang'u et al. 1997; Kilonzo et al. 2005; Makundi et al. 2008; Laudisoit et al. 2009).

Leptospirosis is a water-borne zoonotic disease of worldwide importance, which has been largely neglected in Africa and elsewhere in the tropics (Machang'u 1992). Public health professionals, veterinarians and physicians rarely consider leptospirosis in clinical diagnosis, even in cases of pyrexia of unknown origin. The incidence of leptospirosis in human populations is not well established, and hence this disease does not feature among the priority public health concerns or in national disease prevention programmes in Africa (Machang'u 1992). Rodents and shrews are 
the major reservoirs for leptospirosis; however, maintenance hosts (animals that are capable of acting as a natural source of leptospiral infection for their own species) include various species of mammals, reptiles and amphibians. Rodents shed the microorganisms in urine, and under favourable environmental conditions (alkaline soils, mud, swamps, streams and rivers) the leptospires can survive for years. In the laboratory they can survive for eight years in Korthhof medium in glass tubes in the dark at room temperature and 10 years freeze-dried in vacuum storage in sealed ampoules as preserved cultures (Faine 1982).

Plague is a zoonotic disease for which human infection is primarily acquired through bites of infected rodent fleas with bubonic plague. The natural reservoirs of plague are wild rodents and the causative agent is a bacterium, Yersinia pestis, a member of the family Enterobacteriaceae (Meerburg et al. 2009). Natural transmission of plague to humans remains a possibility in many regions of the world, where foci exist in sylvatic rodent populations. A recent review highlights, in a historical sense, that the number of plague cases is relatively low, the disease is still widely distributed globally, that it has an innate ability to spread rapidly, and clinical symptoms can unfold quickly (Meerburg et al. 2009). Plague remains a disease of major public health importance globally, with several countries in the world reporting cases (WHO 2006b). It persists as a chronic disease among many species of rodents around the world, and outbreaks often occur in unpredictable patterns (Makundi et al. 2008). Outbreaks in Algeria and Democratic Republic of Congo (DRC) have shown that plague may re-emerge in the same areas after a long period of quiescence (WHO 2006a).

Most outbreaks of rodent-borne diseases in humans are commonly related to socio-economic deficiencies such as poor hygiene, poverty and overcrowding. However, the incidences of these diseases are grossly underestimated (Daniel et al. 1992; Lyla et al. 1995; Machang'u et al. 1997). In the current study, we investigated the prevalence of zoonotic disease agents in rodents and shrews captured in selected localities in rural village settings in Swaziland, Tanzania and Namibia.

\section{MATERIALS \& METHODS}

\section{Study sites}

Studies were carried out in Tanzania, Namibia and Swaziland. The studies were based at Berega village $\left(06^{\circ} 10^{\prime} \mathrm{S} 37^{\circ} 08^{\prime} \mathrm{E}\right)$, Gairo division in Central Tanzania, Kake village $\left(18^{\circ} 05^{\prime} \mathrm{S} 21^{\circ} 29^{\prime} \mathrm{E}\right)$ in the Kavango region of Namibia and in the Lobamba village $\left(26^{\circ} 46^{\prime} \mathrm{S} 31^{\circ} 21^{\prime} \mathrm{E}\right)$ of Swaziland.

\section{Animal trapping}

Live trapping of rodents and shrews was conducted from February 2007 to January 2008 in Tanzania, from June 2007 to May 2008 in Namibia and from March 2008 to April 2009 in Swaziland. Trapping of rodents and shrews was carried out inside houses and in peridomestic areas (fallow land surrounding rural houses using Sherman LFA Live Traps $(7.5 \times 9.0 \times 23.0 \mathrm{~cm}$; HB Sherman Traps, Inc., Tallahassee, FL) and locally made live-traps $(12 \times 15 \times 20 \mathrm{~cm})$ consisting of a wooden box with a wire mesh window on one side and snap-back door on the other. Five Sherman and five box traps were set in houses for three consecutive nights at strategic points to increase the capture rate. In peridomestic areas three box and five Sherman traps were placed in trap lines located five metres apart. Traps were inspected every morning and captured animals were identified to species level by a taxonomist. Trapping was done every month for three consecutive trap nights. Trapping was carried in the same houses during the entire study period.

\section{Haemoparasite examination, leptospire evaluation and serological tests}

Live captured animals were anaesthetized with ether and $20-25 \mu 1$ of blood was drawn from the supraorbital vein using a glass capillary. A thick blood smear was prepared on a microscope slide for each animal. Once dried, the slides were immersed in 10\% Giemsa stain (1:10 dilutions) for $30 \mathrm{~min}$ and washed under running water for $10 \mathrm{sec}$, dried and examined under a light microscope $(\times 100$ magnification with immersion oil). Serological tests of selected sera samples from rodents and shrews were conducted for antibodies using the microagglutination assay. Leptospiral antigens were evaluated for serogroups Icterohaemorrhagiae (Sokoine), Grippotyphosa (RM4), Ballum (Ballum), Canicola (Canicola), Sejroe (Hardjo) and Pomona (Pomona). Agglutination was monitored by dark-field microscopy. For isolation, kidney tissue and urine were collected from rodents and shrews. The specimens were cultured in Fletcher's media. Plague serology was conducted using the enzyme-linked immunosorbent assay (ELISA). This assay is specific for antibodies 
Table 1. a, Prevalence of haemoparasites in blood of different species of rodents and shrews in central Tanzania.

\begin{tabular}{lcccccrr}
\hline Rodents and shrews & $\begin{array}{c}\text { Blood smears } \\
\text { tested }\end{array}$ & $\begin{array}{c}\text { Trypanosoma } \\
\text { lewisi }\end{array}$ & Bacillus spp. & Borrelia sp. & $\begin{array}{c}\text { Bipolar } \\
\text { coccobacilli }\end{array}$ & $\begin{array}{c}\text { Total } \\
\text { parasites }\end{array}$ & \% Positive \\
\hline Mastomys natalensis & 317 & 2 & 44 & 0 & 0 & 46 & 14.5 \\
Rattus rattus & 467 & 211 & 16 & 0 & 0 & 227 & 48.6 \\
Crocidura hirta & 83 & 1 & 5 & 2 & 3 & 11 & 13.3 \\
Gerbilliscus vicinus & 32 & 1 & 6 & 0 & 0 & 7 & 21.9 \\
Graphiurus cf. murinus & 3 & 1 & 0 & 0 & 0 & 1 & 33.3 \\
Arvicanthis neumanni & 38 & 0 & 5 & 0 & 0 & 5 & 13.2 \\
Acomys spinosissimus & 3 & 0 & 0 & 0 & 0 & 0 & 0.0 \\
Mus minutoides & 3 & 0 & 0 & 0 & 0 & 0 & 0.0 \\
Aethomys chrysophilus & 2 & 0 & 0 & 0 & 0 & 0 & 0.0 \\
Lemniscomys zebra & 2 & & & & 3 & 0 & 0.0 \\
Total & 950 & 216 & 76 & 2 & 3 & 31.3 \\
\% Positive & 950 & 22.7 & 8.0 & 0.2 & 0.3 & 31.3 \\
\hline
\end{tabular}

b. Prevalence of haemoparasites in blood of different species of rodents and shrews in the Lobamba region of Swaziland.

\begin{tabular}{lccccccc}
\hline Rodents and shrews & $\begin{array}{c}\text { Blood smears } \\
\text { tested }\end{array}$ & $\begin{array}{c}\text { Trypanosoma } \\
\text { lewisi }\end{array}$ & Bacillus spp. & Borrelia sp. & $\begin{array}{c}\text { Bipolar } \\
\text { coccobacilli }\end{array}$ & $\begin{array}{c}\text { Total } \\
\text { parasites }\end{array}$ & Positive \\
\hline Mastomys natalensis & 72 & 1 & 0 & 0 & 0 & 1 & 1.39 \\
Lemniscomys rosalia & 1 & 0 & 0 & 0 & 0 & 0 & 0 \\
Rattus rattus & 2 & 0 & 0 & 0 & 0 & 0 & 0 \\
Total & 75 & 1 & 0 & 0 & 0 & 1 & 1.33 \\
\% Positive & 75 & 1.33 & 0 & 0 & 0 & 1.33 & \\
\hline
\end{tabular}

against the F1 antigen of Yersinia pestis. The test detects specific immunoglobulin G or immunoglobulin $\mathrm{M}$ antibodies to the $\mathrm{F} 1$ fraction due to Yersinia pestis infection.

\section{Data analysis}

The prevalence of haemoparasites and leptospirosis was compared between species, sex, seasons and habitat using General Linear Model of the program STATISTICA (Stat Soft Inc.)

\section{RESULTS}

\section{Small mammal species}

In central Tanzania, ten rodent and shrew species were captured (Rattus rattus, Mastomys natalensis, Crocidura hirta, Graphiurus cf. murinus, Arvicanthis neumanni, Acomys spinosissimus., Mus minutoides, Aethomys chrysophilus, Gerbilliscus vicinus and Lemniscomys zebra). In Namibia, eight species of rodents were captured (Gerbilliscus leucogaster, Steatomys pratensis, Mus indutus, M. natalensis, Lemniscomys rosalia, Thallomys paedulcus, Saccostomus campestris and Rhabdomys pumilio). In
Swaziland, a total of three species was captured (R. rattus, L. rosalia and $M$. natalensis).

\section{Screening for haemoparasites}

A total of 1051 small mammal blood samples from Tanzania, Swaziland and Namibia were screened for haemoparasites. Tables $1 \mathrm{a}$ and $1 \mathrm{~b}$ show the haemoparasites observed in samples from rodents and shrews in Tanzania and Swaziland (obtained in January during the wet season). The results show the presence of Trypanosoma lewisi in the blood of rodents and shrews, with $R$. rattus accounting for a higher percentage of all positive cases. No haemoparasites were observed in the blood samples from Namibia. There were significant seasonal variations $\left(F_{6,70}=86.13, P=\right.$ $0.000)$ in the number of haemoparasites observed between the species studied in Tanzania. Rattus rattus harboured more haemoparasites than the other species (Fig. 1). There were no significant seasonal effects on the number of haemoparasites in the species studied $(P \geq 0.05)$ but significant $\left(F_{6,0}=2.31, P=0.043\right)$ interactions between species and season were observed. Haemoparasites were 


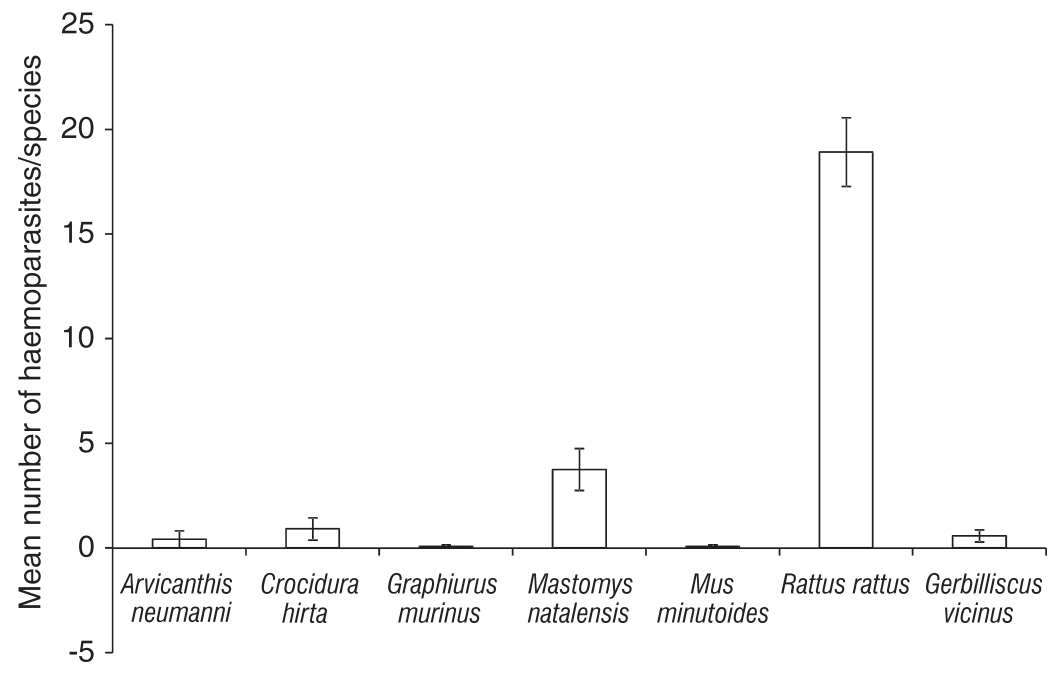

Fig. 1. Mean number of haemoparasites in different species of rodents and shrews in Central Tanzania.

more prevalent in Rattus rattus during the wet season than in the dry season, whereas they were more prevalent in the dry than wet season in M. natalensis (Fig. 2). Significant variations $\left(F_{1,912}=\right.$ $78.34, P=000)$ in the number of haemoparasites were observed in the two habitats studied. More haemoparasites were observed in those animals captured inside rural houses than in peridomestic areas (Figs $3 \& 4$ ).

\section{Plague}

All 452 rodent and shrew blood samples from central Tanzania were negative for antibodies against the F1 antigen of $Y$. pestis (Table 2). Two of
53 blood samples of rodents from Namibia were serologically positive for antibodies against the F1 antigen of $Y$. pestis. The two positive blood samples originated from two different rodent species, R. pumilo and G. leucogaster (Table 2). One of the samples was obtained in June (dry season) while the other was collected in March (wet season).

\section{Leptospirosis}

Table 3a shows the seroprevalence of different serogroups of Leptospira interrogans in rodents and shrews blood at different titres. Most of the samples tested were positive at low titres for

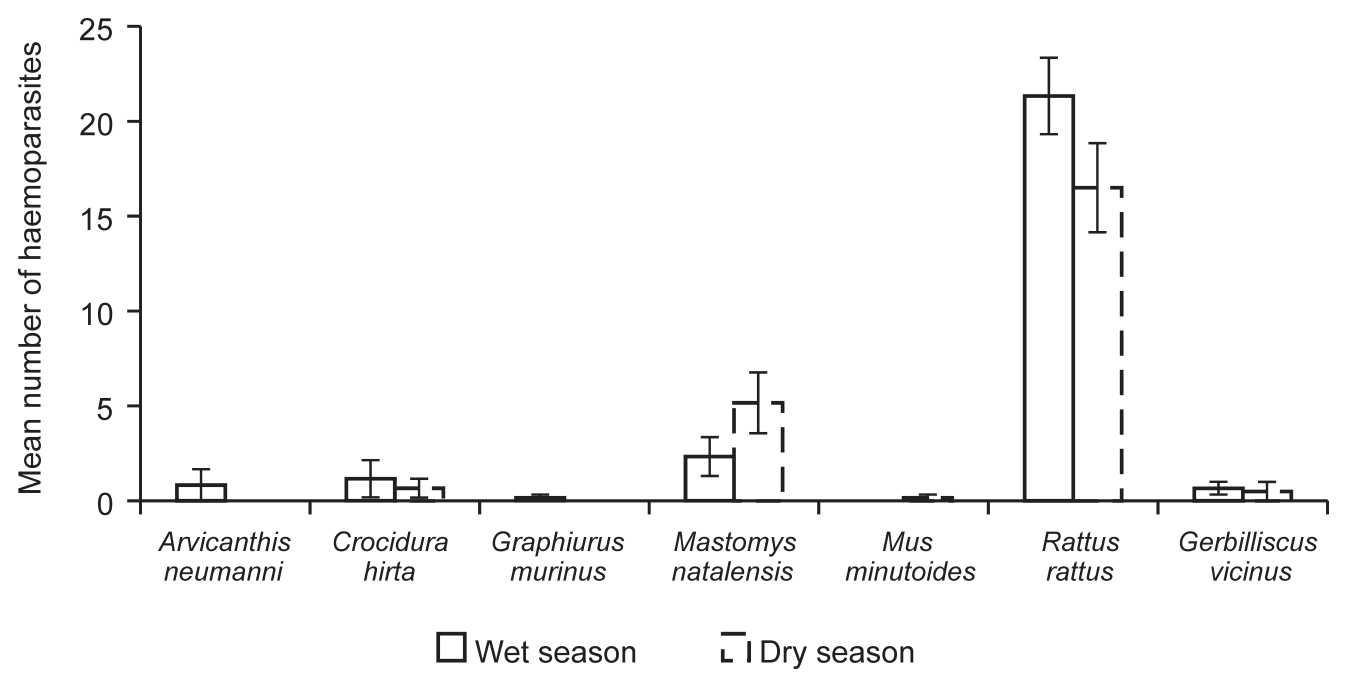

Fig. 2. Seasonal variations in the mean prevalence of haemoparasites in different species of rodents and shrews in central Tanzania. 


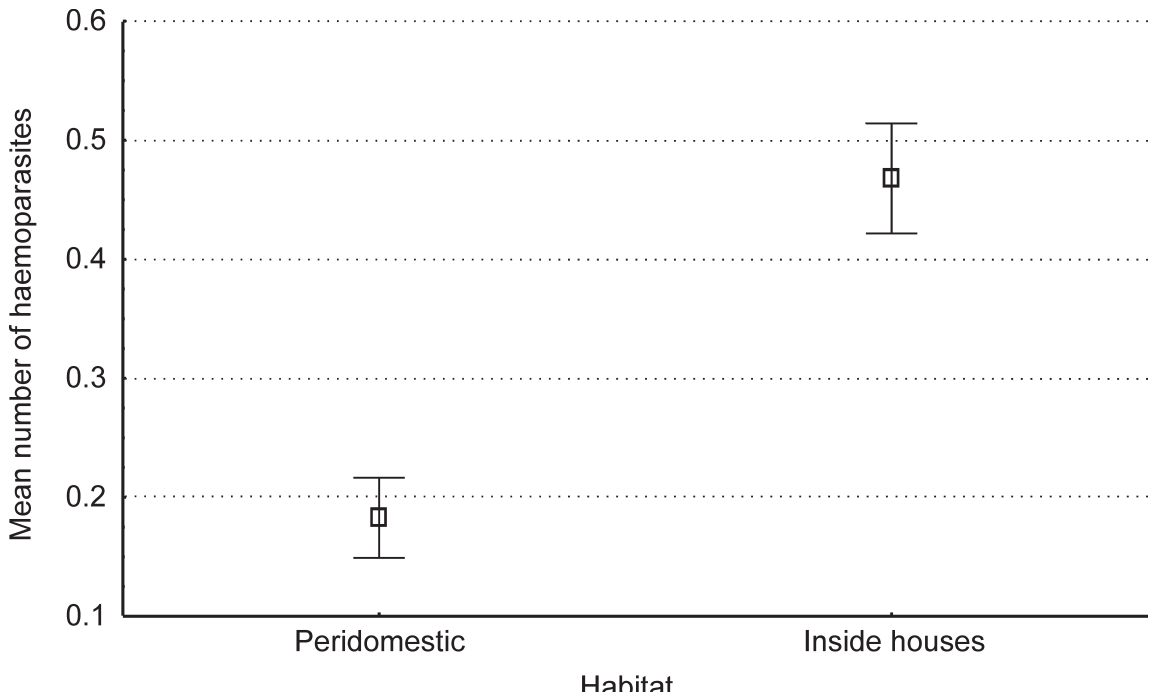

Fig. 3. Mean number of haemoparasites observed in animals captured in peridomestic areas and inside houses in central Tanzania.

leptospirosis. Blood samples from M. minutoides and A. spinosissimus were negative to all serovars of leptospirosis. R. rattus, M. natalensis and C. hirta had higher proportions of individuals which tested positive for leptospirosis than the rest of the species (Table $3 b$ ).

An analysis of the results shows that there was a significant difference $\left(F_{5,342}=3.39, P=0.005\right)$ in rodent and shrew species involved in the study area in Tanzania ( $R$. rattus $0.147 \pm 0.3 ; M$. natalensis
$0.168 \pm 0.033 ;$ C. hirta $0.285 \pm 0.63 ;$ G. cf. murinus $1 \pm 0.26$; A. neumanni $0.13 \pm 0.07$; and $G$. vicinus $0.4 \pm 0.14)$. There were significant variations $\left(F_{1}\right.$, $80=5.39, P=0.02)$ in the prevalence of leptospirosis between two seasons. Higher prevalence of leptospirosis was observed in those animals captured during the wet seasons $(0.937 \pm 0.17)$ than in the dry season $(0.35 \pm 0.17)$. There was also a significant seasonal variations $\left(F_{7,80}=4.81, P=\right.$ 0.000 ) of prevalence between species ( $R$. rattus

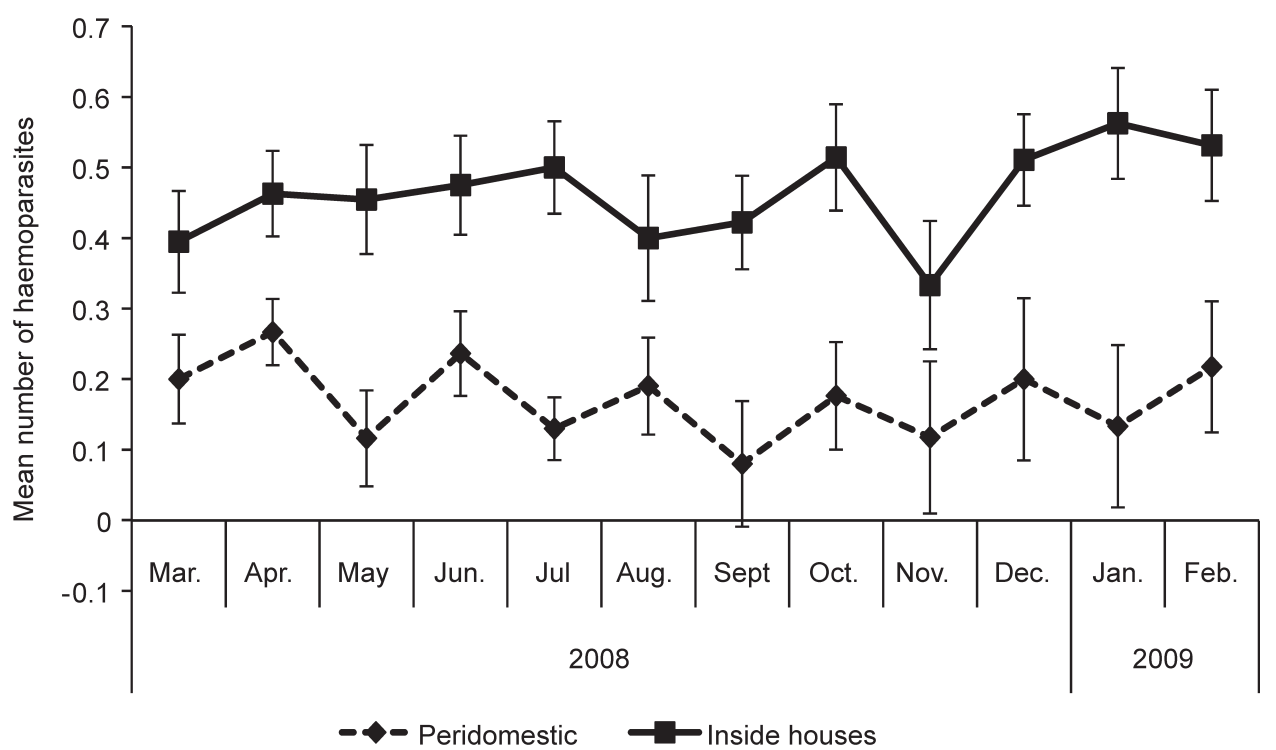

Fig. 4. Seasonal trends of haemoparasites in rodents and shrews captured in peridomestic and inside houses in central Tanzania. 
Table 2. Seroprevalence of antibodies against the F1 antigen of Yersinia pestis in blood of rodents and shrews from central Tanzania and the Kavango region in Namibia.

\begin{tabular}{lrc}
\hline Species & Tanzania* & Namibia* $^{*}$ \\
\hline Acomys spinosissimus & $2(0)$ & - \\
Arvicanthis neumanni & $34(0)$ & - \\
Crocidura hirta & $43(0)$ & - \\
Graphiurus cf. murinus & $3(0)$ & - \\
Mastomys natalensis & $145(0)$ & $27(0)$ \\
Mus minutoides & $2(0)$ & - \\
Rattus rattus & $197(0)$ & - \\
Gerbilliscus vicinus & $21(0)$ & - \\
Lemniscomys zebra & $4(0)$ & $2(0)$ \\
Aethomys chrysophilus & $1(0)$ & - \\
Mus indutus & - & $3(0)$ \\
Rhabdomys pumilio & - & $2(1)$ \\
Saccostomus campestris & - & $3(0)$ \\
Steatomys pratensis & - & $8(0)$ \\
Gerbilliscus leucogaster & - & $6(1)$ \\
Thallomys paedulcus & - & $2(0)$ \\
Total & $452(0)$ & $53(2)$ \\
\hline
\end{tabular}

*Numbers in brackets indicate positive samples.

$1.92 \pm 0.35 ;$ M. natalensis $1.75 \pm 0.35 ;$ C. hirta $0.83 \pm$ 0.35 ; G. cf. murinus $0.16 \pm 0.35$; A. neumanni $0.25 \pm$ $0.35 ;$ A spinosissimus $0.00 \pm 0.35 ;$ M. minutoides $0.00 \pm 0.35$ and $G$. vicinus $0.25 \pm 0.35$ ). No variation in the prevalence of leptospirosis was observed between the two habitats $(P \geq 0.05)$, but significant variations $\left(F_{1,344}=4.78, P=0.029\right)$ between male and female were observed. Prevalence of leptospirosis was higher in females $(0.217 \pm 0.02, n=$ $198)$ than in males $(0.126 \pm 0.03, n=150)$.

\section{DISCUSSION}

The presence of T. lewisi in the blood of a large proportion of individuals of $R$. rattus raises a public health concern because of the commensal nature of this species. Rattus rattus is thought to be a potential reservoir and vector of human or animal pathogenic trypanosomes, including T. rhodesiense, T. gambiense, T. brucei, T. congolense, T. vivax and T. suis (Silayo 1992; Juha 2003; Powelczyk et al. 2004). Although it has been reported that T. lewisi is a common blood parasite of rodents, the pathogenicity of this protozoan has not been established (Silayo 1992).

The presence of spirochetes supports previous reports on the potential role of rodents and shrews as reservoirs of Borrelia spp. and Leptospira spp. (Gratz 1977; Machang'u et al. 2003). Spirochetes have been detected in ticks (Ixodes persulcatus) and in wild rodent hosts in Russia (Sato et al. 1996). The presence of bacilli in rodent and shrew blood smears was not entirely unexpected since rodents are known to be carriers of various bacterial organisms (Gratz 1994). Although coccobacilli were observed in the blood smears of rodents and shrews trapped in central Tanzania, serological tests on blood sera from the same animals by ELISA were negative for antibodies against the F1 antigen of $Y$. pestis. This indicates that Gairo division in Central Tanzania was potentially plague-free. Other localities in northern and northeastern Tanzania have been reported to be plague endemic (Davis et al. 2006; Kilonzo et al. 2005; Makundi et al. 2008) The presence of antibodies against the $\mathrm{F} 1$ antigen of $\mathrm{Y}$. pestis in the blood of two rodent species, $R$. pumilio and G. leucogaster, in the Kavango region, Namibia, suggests that this is an enzootic plague area. The Kavango region is outside the known plague endemic foci, which are centred in the Ohangwema and Oshikoto regions of Namibia where human cases were previously reported (Groepe 1993; Shangula 1998). The current findings reinforce the need for regular plague surveillance in rodents in the Kavango region of Namibia in order to reduce the risks of human infections particularly because plague is now regarded as a globally re-emerging disease, with Africa reporting more cases than the rest of the world (WHO 2006b).

Leptospirosis is widely prevalent in rodents, shrews, humans and livestock in some parts of Tanzania (Machang'u 1992; Machang'u et al. 1997; Mgode et al. 2006). In central Tanzania, leptospirosis was most prevalent in species captured in houses and peridomestic areas where they interact with humans thus raising the potential of human infection. Mastomys natalensis and C. hirta were also trapped in fallow land, maize field, vegetable gardens and sugar cane plantations. These sites are associated with human activities in the rural settlements. Some farming activities, particularly for crops with high water needs such as rice, sugarcane and vegetables, predispose humans to leptospirosis infection through rodent urine-contaminated environments (Faine 1982; Faine et al. 1999). Leptospirosis is a major health hazard in rural communities in developing countries, particularly among the rural poor who are at greatest risk of exposure to infection emanating from long hours in the field and interactions with rodents. In addition they lack early medical intervention when they become infected (Meerburg et al. 2009). Recently, 
Table 3. a, Seroprevalence of different serogroups of Leptospira interrogans in blood of rodents and shrews from central Tanzania.

\begin{tabular}{lcccccc}
\hline Titres & \multicolumn{5}{c}{ Serogroups tested } \\
\cline { 2 - 7 } & $\begin{array}{c}\text { Ictero. } \\
(n=350)\end{array}$ & $\begin{array}{c}\text { Pomona } \\
(n=350)\end{array}$ & $\begin{array}{c}\text { Hardjo } \\
(n=350)\end{array}$ & $\begin{array}{c}\text { Ballum } \\
(n=350)\end{array}$ & $\begin{array}{c}\text { Grippo. } \\
(n=350)\end{array}$ & $\begin{array}{c}\text { Canicola } \\
(n=350)\end{array}$ \\
\hline $1: 20$ & 15 & 3 & 2 & 0 & 1 & 1 \\
$1: 40$ & 9 & 5 & 2 & 2 & 1 & 2 \\
$1: 80$ & 8 & 1 & 0 & 1 & 3 & 1 \\
$1: 160$ & 4 & 0 & 0 & 0 & 5 & 4 \\
$1: 320$ & 0 & 1 & 0 & 3 & 1.43 & 1.14 \\
Total & 36 & 10 & 4 & 0.89 & & 4 \\
$\%$ Positive & 10.29 & 2.86 & 1.14 & & & \\
\hline
\end{tabular}

b, Species-specific seroprevalence of different serogroups of Leptospira interrogans in blood of rodents and shrews from central Tanzania.

\begin{tabular}{|c|c|c|c|c|c|c|c|c|}
\hline Species & $\begin{array}{l}\text { No. of sera } \\
\text { tested }\end{array}$ & Ictero. & Pomona & Hardjo & Ballum & Grippo. & Canicola & $\begin{array}{c}\text { Total } \\
\text { positive }\end{array}$ \\
\hline Rattus rattus & 157 & 15 & 2 & 1 & 1 & 0 & 2 & 21 \\
\hline Mastomys natalensis & 124 & 12 & 6 & 2 & 1 & 2 & 0 & 23 \\
\hline Arvicanthis neumanni & 23 & 0 & 0 & & 1 & 1 & 1 & 3 \\
\hline Gerbilliscus vicinus & 7 & 2 & 0 & 0 & 0 & 0 & 1 & 3 \\
\hline Graphiurus cf. murinus & 2 & 1 & 1 & 0 & 0 & 0 & 0 & 2 \\
\hline Crocidura hirta & 35 & 6 & 1 & 1 & 0 & 2 & 0 & 10 \\
\hline Acomys spinosissimus & 1 & 0 & 0 & 0 & 0 & 0 & 0 & 0 \\
\hline Mus minutoides & 1 & 0 & 0 & 0 & 0 & 0 & 0 & 0 \\
\hline Total & 350 & 36 & 10 & 4 & 3 & 5 & 4 & 62 \\
\hline
\end{tabular}

Taylor et al. (2008) reported seropositive rodents for leptospirosis and toxoplasmosis in an urban environment in Durban, South Africa. Our observations in the current study are further evidence that rodent-borne zoonoses are widespread in rodents, which could predispose rural communities to infection.

Generally, there is under-reporting of rodentborne zoonoses and insufficient attention is paid to the diagnosis of these important diseases in sub-Saharan Africa. According to Taylor et al. (2008) the prevalence of zoonotic agents in rodents was higher in informal settlements without improved sewage systems and housing. In rural areas in sub-Saharan Africa, communities live in settlements surrounded by habitats that are suitable for harbouring large numbers of rodents in some seasons, which increases the likelihood of intense human-rodent interactions. With increasing human population and encroachment into natural habitats, which harbour high diversity of rodents, frequent rodent-human interactions could increase the potential for contracting some zoonotic diseases, thus posing serious public health problems in Africa.

In Africa, these rodent-borne zoonoses either cause diseases, which go undiagnosed or are misdiagnosed due to lack of information on the prevalence of the causative agents (Begon 2003). Several other zoonoses that were not the subject of the current investigation include arenaviruses and hantaviruses, which cause haemorrhagic fevers in humans. These have recently been found in rodents in Tanzania (Mills 1999; Borremans et al. 2011; Goüy de Bellocq et al. 2010; Günther et al. 2010).

\section{Reducing the risks to infection by rodent-borne zoonoses}

It is very important to reduce the hazards of rodent- and shrew-borne diseases in areas where humans, domestic animals and rodents are living close to each other (Meerburg et al. 2009). Taylor et al. (2008) reported some of the principles that contributed to the success of the Boston Model to control rodents and their diseases at Cato Crest in 
Durban, South Africa. The conditions in Cato Crest in Durban bear similarities to rural settings in Tanzania, Swaziland and Namibia, which suggests that the principles applied for reducing the risks of rodent-borne zoonotic infections could be adopted by these countries, but based on a better understanding of the local rodent species, kind of zoonoses harboured and the ecology of these species. Involving the local communities in management of rodents has been shown to be effective in reducing commensal rodent infestations (Belmain et al. 2008), and therefore it provides an opportunity for reducing the risks of zoonotic infections in rural communities in these countries.

\section{ACKNOWLEDGEMENTS}

The work reported was financed by the Southern African Development Community (SADC) Secretariat through the Implementation and Coordination of Agriculture Research and Training (ICART) project with support from the European Union. The contents of this document are the sole responsibility of the authors and can under no circumstances be regarded as reflecting the position of the SADC Secretariat or the European Union. We thank all researchers involved in this study and the governments of Tanzania, Namibia and Swaziland. We also thank the reviewers for comments that greatly improved our manuscript.

\section{REFERENCES}

BEGON, M. 2003. Disease: health effects on humans, population effects on rodents. In: Rats, Mice and people: Rodent Biology and Management, (eds) G.R. Singleton, L. Hinds, C.J. Krebs \& M.D. Spratt, pp. 13-19. Australia Centre for International Agricultural Research, Canberra.

BELMAIN, S.R., DLAMINI, N., EISEB, S., KIRSTEN, F., MAHLABA, T., MAKUNDI, R., MALEBANE, P., MALTITZ, E.V., MASSAWE, A., MONADJEM, A., MULUNGU, L., SIWIYA, E., TAYLOR, P.J. \& TUTJAVI, V. 2008. The ECORAT project: developing ecologically-based rodent management for the southern African region. International Pest Control 50(3): 136-138.

BORREMANS, B., LEIRS, H., GRYSEELS, S., STEPHAN G., MAKUNDI, R. \& GOÜY DE BELLOCQ, J. 2011. Presence of Mopeia virus, an African arenavirus, related to biotope and individual rodent host characteristics: implications for virus transmission. Vector Borne and Zoonotic Diseases 11(8): 1125-1131

DANIEL, E., BEYENE, H. \& TESSEMA, T. 1992. Relapsing Fever in children: demographic, social and clinical features. Ethiopian Medical Journal 30: 207-214.

DAVIS, S., MAKUNDI, R.H., MACHANG'U, R.S. \& LEIRS, H. 2006. Demographic and spatio-temporal variation in human plague at a persistent focus in Tanzania. Acta Tropica. 100: 133-141.
FAINE, S. 1982. Guidelines for the Control of Leptospirosis. World Health Organisation, Geneva, Switzerland.

FAINE, S., ADLER, B., BOLIN, C. \& PEROLAT, P. 1999. Leptospira and Leptospirosis, 2nd edn. MediSci, Melbourne, Australia.

GRATZ, N.G. 1994. Rodents as carriers of diseases. In: Rodent Pests and their Control, (eds) A.P. Buckle \& R.H. Smith, pp. 85-108. CAB International, Cambridge, U.K.

GRATZ, N.G. 1997. The burden of rodent-borne diseases in Africa south of Sahara. Belgian Journal of Zoology 127: 71-84.

GOÜY DE BELLOCQ, J., BORREMANS, B., KATAKWEBA, A., MAKUNDI, R., STUART, J.E.B., BECKER-ZIAJA, B., GÜNTHER, S. \& LEIRS, H. 2010. Sympatric occurrence of three arenaviruses in Morogoro, Tanzania. Emerging Infectious Diseases 16(4): 692-695.

GÜNTHER, S., HOOFD, G., CHARREL, R., RÖSER, C., BECKER-ZIAJA, B., GRAHAM LLOYD, G., SABUNI, C., VERHAGEN, R., VAN DER GROEN, G., KENNIS, J., KATAKWEBA, A., MACHANG'U, R., MAKUNDI, R. \& LEIRS, H. 2010. A Mopeia-related arenavirus in Mastomys natalensis in Morogoro, Tanzania. Emerging Infectious Diseases 15(12): 2008-2012.

GROEPE, M.A. 1993. A survey of small mammals and their fleas in northern Namibia and their importance in plague. Unpublished M.Sc. dissertation, University of Zimbabwe, Harare, Zimbabwe.

JUHA, L., JUKKA, T.L., HAINGOTIANA, R. \& WRIGHT, P.C. 2003. Trypanosome parasites in the invading Rattus rattus and endemic rodents in Madagascar. In: Rats Mice and People: Rodent Biology and Management, (eds) G.R. Singleton, L. Hinds, C.J. Krebs \& M.D. Spratt, pp. 37-39. Australia Centre for International Agricultural Research, Canberra.

KILONZO, B., MHINA, J., SABUNI, C. \& MGODE, G. 2005. The role of rodents and small carnivores in plague endemicity in Tanzania. Belgian Journal of Zoology 135 (Suppl.): 119-125.

KORBAWIAK, G., RYCHLIK, L., NORWAKOWSK, W. \& WITA, I. 2005. Natural infestation of small mammals with blood parasites on the borderland of boreal and temperate forest zones. Acta Theriologica 50: $31-42$.

LAUDISOIT, A., NEERINCKX, S., MAKUNDI, R.H., LEIRS, H. \& KRASNOV, B.R. 2009. Are local plague endemicity and ecological characteristics of vectors and reservoirs related? A case study in north-east Tanzania. Current Zoology 55(33): 200-211.

LYLA, A.AL-G., SHIHAB, A.AL.M., AYOOLA, E., KHALID, S.AL-K., KAMAL, I.G. \& AHMED, O.AL-O. 1995. Relapsing fever in Saudi Arabia; Report of two cases. Online at: http://www.niaid.nih.gov (accessed 16 August 2011).

MACHANG'U, R.S. 1992. Leptospirosis in tropical and subtropical Africa. In: Leptospirosis on the African Continent, (ed.) W.J Terpstra, pp. 106-111. Proceedings CEC/STD3 Research Meeting, Harare, Zimbabwe.

MACHANG'U, R.S., MGODE, G. \& MPANDUJI, D. 1997. Leptospirosis in animals and humans in selected areas of Tanzania. Belgian Journal of Zoology 127: 97-104.

MACHANG'U, R.S., MGODE, G.F., ASSENGA, J., 
MHAMPHI, G., HARTSKEERL, R. \& GORIS, M. 2003. Serological and molecular characterization of leptospira serovar Kenya from captive African giant pouched rats, Cricetomys gambianus. In: Rats Mice and People: Rodent Biology and Management, (eds) G.R. Singleton, L. Hinds, C.J. Krebs \& M.D. Spratt, pp. 40-42. Australian Centre for International Agricultural Research, Canberra.

MAKUNDI, R.H., MASSAWE, A.W., MULUNGU, L.S., KATAKWEBA, A., MBISE, T.J. \& MGODE, G. 2008. Potential mammalian reservoir in bubonic plague outbreak focus in Mbulu District, northern Tanzania, in 2007. Mammalia 72(3): 253-257.

MEERBURG, G.M., SINGLETON, G.R. \& KIJLSTRA, A. 2009. Rodent-borne diseases and their risks for public health. Critical Reviews in Microbiology 35: 221-270.

MGODE, G.F., MACHANG'U, R.S., GORIS, M.G., ENGELBERT, M., SONDIJ, S. \& HARTSKEERL. R.A. 2006. New Serovar Sokoine of serogroup Icterohaemorrhagiae from cattle in Tanzania. International Journal of Systematic and Evolutionary Microbiology 56: 593-597.

MILLS, J.N. 1999. The role of rodents in emerging human diseases: examples from the hantaviruses and arenaviruses. In: Ecologically-based Rodent Management, (eds) G. Singleton, L. Hinds, H. Leirs \& Z. Zhang, pp. 134-160. Australian Center for International Agricultural Research, Canberra, Australia.

POWELCZYK, A., BEJER, A., BEHNKE, J.M., GILBERT,
F.S. \& SINSKI, E. 2004. Factors affecting the component community structure of haemoparasites in common voles (Microtus arvalis) from the Mazury Lake District region of Poland. Parasitology Research Journal 92(4): 270-284.

SATO, Y., MIYAMOTO, K., IWAKI, A., MASUZAWA, T., YANGIHARA, Y. \& KORENBERG, E.I. 1996. Prevalence of lyme disease spirochetes in Ixodes persulcatus and wild rodents in Far East Russia. Journal of Applied Environmental Microbiology 62 (10): 3887-3889.

SHANGULA, K. 1998. Successful plague control in Namibia. South African Medical Journal 88: 1428-1430.

SILAYO, R.S. 1992. Rodent and protozoan parasites of veterinary and medical importance. In: Proceedings of International Workshop on the Economic Importance and Control of Rodents, (ed.) R.S. Machang'u, pp. 76-79. Mzumbe Book Project, Morogoro, Tanzania.

TAYLOR., P.J., ARNTZEN, L., HAYTER, M., IVES, M., FREAN, J. \& BELMAIN, S. 2008. Understanding and managing sanitary risks due to rodent zoonoses in an African city: beyond the Boston Model. Integrative Zoology 3: 38-50.

WORLD HEALTH ORGANIZATION. 2006a. Bubonic and pneumonic plague in Uganda 2006. Weekly Epidemiological Records 81: 241-242.

WORLD HEALTH ORGANIZATION. 2006b. Interregional meeting on prevention and control of plague. Antananarivo, Madagascar, 7-14 April 2006. World Health Organisation, Geneva.

Responsible Editor: P.J Taylor 